УДК 37.014.53 : 37.011: 001.8

DOI https://doi.org/10.32837/apfs.v0i32.1024

\author{
С.В. Копилова \\ ORCID ID: https://orcid.org/0000-0002-7577-839X \\ кандидат педагогічних наук, доцент, \\ доцент кафедри соціальної роботи, соиіальної педагогіки та соиіології \\ Херсонського державного університету
}

\title{
АНТРОПОЦЕНТРИЧНА СИСТЕМА ЯК ОБ'ЄКТ СУЧАСНОГО ПІЗНАННЯ
}

Постановка проблеми. Індикатором еволюції науки є зміна об'єкта пізнання під впливом трансформації наукової картини світу. Наукова картина світу як цілісний образ світу створюється за участю свідомості. «У ній синтезуються не тільки знання про природу або, більш широко, про Універсум, але відбувається злиття цих знань із ціннісними, світоглядними установками, що відбивають присутність конкретно-історичного суб'єкта у знанні» [1, с. 21]. Наукова картина світу тісно пов'язана зі світоглядом, втілюючи у світоглядних принципах спосіб інтерпретації загальнонаукових ідей.

$\mathrm{У}$ науковій картині світу, яка відповідає класичній науці, знайшли відображення аспекти статики й динаміки. «Класична наука основну увагу приділяла стійкості, порядку, однорідності, рівновазі - параметрам, які характеризують лінійні співвідношення" [2]. У класичній науці об'єктом педагогічного дослідження є спочатку виховний, а надалі - навчальний процес, а предметом - педагогічні умови.

$\mathrm{У}$ некласичній науці можна виділити два етапи еволюційного руху. Перший пов'язаній зі становленням квантово-релятивістської фізики, парадокси якої продемонстрували обмеження електродинамічної картини світу. У новій картині світу єдність була втрачена: специфічні риси мікрооб'єктів стали відображатись через два додаткові уявлення - корпускулярне та хвильове. Другий етап зумовлений розвитком кібернетики, синергетики, теорії систем тощо. Це зумовило «перехід від елементаристського сутнісно-онтологічного пояснення до пояснення, заснованого на універсально-абстрактних конструкціях. У некласичній науці як об'єкт дослідження розглядаються системи. «Відбулось оновлення категорій «некласичної філософії науки»: соціальна (емпірична) суб'єктність, релятивність, партикулярність, суб'єкт-об'єктність наукового знання» [3]. Наукове мислення стало орієнтуватись на наявність у цілісного об'єкта таких властивостей та якостей, які не властиві частинам; відбулось усвідомлення неправомірності зведення складного до простого, цілого до частини.

На етапі постнекласичної науки виникли передумови іншого бачення реальності порівняно 3 тим, яке пропонувала корпускулярно-хвильова картина світу. Оскільки процес самоорганізації має еволюційне значення, відновився інтерес дослідників до систем, що еволюціонують, але тепер уже на якісно іншому рівні. Виникла необхідність виявлення специфіки й термінологічного позначення нового класу системних об'єктів. Для вирішення цієї задачі необхідно осмислити тенденції розвитку різних видів знання.

Аналіз досліджень. Спочатку системи розглядалися як такі, що саморегулюються. Як зазначає В. Василькова, некласична картина світу виростає зі світосприйняття другої половини XX століття стадії різкого прискорення соціальних процесів, ущільнення темпу соціальних змін, пошуку синкретичних (холістичних) форм свідомості й соціального (індивідуального) існування. Ця картина світу визнає наявність у світі замкнених систем, що діють як механізми [2, с. 27-28]. Основним для них є збереження рівноваги (адаптивні системи). Під адаптивною розуміють систему, що автоматично змінює алгоритми свого функціонуванні i (іноді) свою структуру з метою збереження або досягнення оптимального стану під час зміни зовнішніх умов. У ній людина розглядається як така, що підпорядковує собі природу.

Завдяки синергетиці відбувся перехід до розгляду систем, які самоорганізовуються (відкрита система, взаємодіюча система, за Я. Пономарьовим). "Системні дослідження мають стійку тенденцію до розширення сфери своїх наукових пошуків, включенню до неї аналізу самих різних типів систем. Поведінка цих систем настільки різноманітна і специфічна, що виникає питання про неможливість вичерпних характеристик у рамках якоїсь одної формальної теорії, але зберігається актуальність пошуку понятійно-концептуальної основи для змістовного розуміння найбільш широких типів цих об'єктів [1, с. 151]. Дослідники звернули увагу на сукупність фактів і дослідницькі об'єкти, які раніше не вивчалися наукою.

Самоорганізація розглядається як процес, що приводить до утворення нових структур. Завдяки синергетиці наукова картина світу збагачується принципами відкритості й комунікативності. Оскільки такі системи почали розглядатись у кібернетиці, термін «система, що самоорганізовується» був запропонований У. Ешбі у 1947 році. 
За В. Ебелінгом, ознаками такої системи є: 1) постійний приток негативної ентропії; 2) нелінійність динамічних рівнянь системи (збудження); 3) перевищення критичних значень відхилення від рівноваги; 4) кооперативний характер процесів у системі; 5) посилення відхилень від нестійких станів; 6) відбір та спонтанна самоорганізація на макромолекулярному рівні; 7) принцип еволюції Пригожина-Гленсдорфа [4].

Система, що самоорганізовується, - складна динамічна система, здатна при зміні зовнішніх або внутрішніх умов її функціонування і розвитку зберігати або удосконалювати свою організацію 3 урахуванням минулого досвіду. Як такі системи розглядаються жива клітина, організм, біологічна популяція, людський колектив. Така система може мати різне позначення: «взаємодіюча система», «відкрита система», морфогенетична система (автопоезна). Як зазначає Я. Пономарьов, недостатньо досліджувати ізольовано взятий об'єкт. Справжнім об'єктом наукового аналізу може бути тільки взаємодіюча система [4].

«В основному світ складається з відкритих систем, які інтенсивно обмінюються енергією, речовиною, інформацією з оточуючим середовищем i характеризуються іншими принципами - розупорядкованістю, різноманітністю, нестійкістю, нерівноважністю, нелінійними співвідношеннями» ... Природний порядок світобудови не є назавжди даним, матерія не інертна, їй властиві джерела саморуху та внутрішньої активності [2, с. 30].

М. Маруяма позначає системи, що самоорганізовуються як морфогенетичні. Залежно від складності систем виділяють детерміновані, тобто із завчасно заданим параметром управління, i недетерміновані - з пошуком оптимального рішення шляхом проб і помилок. У житті, на відміну від керованих систем через зовнішній регулятор (кібернетичні системи), ми зустрічаємося із системами, у яких ряд внутрішніх взаємодій змінюють поведінку від початкового рівня. Саме в основі такого роду систем лежить процес морфогенезу». Морфогенетичні системи складні за структурою та умовно передбачувані у поведінці. Для опису такого роду систем уводяться поняття «автопоезис» або «самотворчість», «самовиробництво» $\mathrm{i}$ «самореферентність» (властивість системи якимось чином відноситись до самої себе). Аналізовані якості належать до живих систем і можуть бути реалізовані всередині їх. По своїй суті ми стикаємось з системами, які характеризуються відкритістю та здатні до обміну енергією й речовиною із зовнішнім середовищем. Тут не зовнішній стимул, але внутрішній стан системи стає домінуючим у визначенні іiї поведінкового патерну; оточуюче середовище виступає як джерело впливу, що приводить до спонтанних змін внутрішньої структури системи [6].
Мета - поставити проблему еволюційної зміни об'єкта некласичної науки й окреслити перспективи їі вирішення у постнекласичній науці. Завдання: 1) на основі критичного аналізу факторів виділити суперечності у науці, які зумовлюють зміну парадигми некласичної науки, необхідність перегляду наукової картини світу, а також тенденції трансформації об'єкта некласичної науки; 2) проаналізувати можливості термінологічного позначення нового об'єкта дослідження постнекласичної науки.

Методологія. Традиційно для побудови нової концепції застосовується індуктивний метод, який передбачає узагальнення й синтез наявного знання. Але, як справедливо зауважує В. Стьопін, для побудови теорії необхідно мати деяку модель. Функцію такої моделі виконує наукова картина світу. В ситуації її оновлення науковець втрачає можливість користуватись методом індукції. Для упорядкування набутого знання, надання їм концептуальної форми нами розроблено інваріанту модель антропоцентричної системи. Вона здатна виконати евристичну функцію, у тому числі для обгрунтування самої себе.

У найбільш загальному вигляді інваріантну модель антропоцентричної системи можна представити як єдність індивіда і суспільства (якість життя), суб’єкта і об’єкта (якість діяльності). Даній моделі відповідає сукупність факторів, запропонована В. Петрущиком. Він виділяє об'єктивний, людський, суб'єктивний, особистісний фактори [7]. Оскільки поняття «людина» є нерядоположним 3 іншими трьома, уважаємо за необхідне замінити його на поняття «індивідуальний фактор».

Для аналізу тенденцій трансформації об'єкта некласичної науки звернемось до аналізу індивідуального, суб'єктивного, особистісного факторів. На основі аналізу першого виникає можливість встановлення джерел перегляду квантово-релятивістської наукової картини світу. Завдяки аналізу суб'єктивного фактору (якісний аналіз) стає можливим встановлення суперечностей, неявного знання. Аналіз особистісного фактору (зміна парадигм) дає можливість конкретизувати новий об’єкт пізнання, що відповідає постнекласичній науці.

Виклад матеріалу. Насамперед важливо виходити 3 індивідуальної активності науковців, завдяки чому відбулось кількісне накопичення наукового знання. Зосередимо увагу на важливих теоретичних положеннях, які необхідні для обIрунтування нового об'єкта пізнання у науці.

У XX столітті майже одночасно у різних науках відбулось оформлення ряду фундаментальних теорій: теорії біологічної еволюції, теорії нестаціонарного Всесвіту, концепції ноосфери, синергетики тощо. Будуючи поєднані спільним принципом еволюції, «теорії відкрили перспективи для з'ясування взаємозв'язків між основними поверхами 
світобудови - неживою, живою й соціальною матерією, дозволили поєднати результати, отримані в різних галузях знання, в єдиній загальнонауковій картині світу» [3]. Завдяки еволюційному принципу створено передумови синтезу наукового знання.

Кількісні параметри накопиченого знання змушують звертатись до узагальнюючих праць. Це дозволяє уникнути перевантаження змісту дослідження другорядними питаннями й зосередитись на розв'язанні поставлених задач. На основі теоретичного аналізу, проведеного О. Болдачовим (2000), В. Васильковою (1999), В. Сьопіним (2000), виділимо важливі моменти.

Природниче обгрунтування ідеї універсального еволюціонізму представлене в учінні про еволюцію біосфери у ноосферу В. Вернадського. «Біосфера є цілісною системою, що еволюціонує у взаємозв' язку з неорганічними умовами, є етапом у розвитку матерії. Ї̈̈ розвиток здійснюється під впливом внутрішніх взаємовідношень структурних компонентів і антропогенних факторів; можуть виникати такі стани, які приводять до якісної зміни складових підсистем, структури біосфери. Єдність мінливості й стійкості в біосфері $€$ результат взаємодії компонентів, а їх співвідношення виступає як діалектична єдність спадковості та мінливості, тому сама стійкість є стійкість процесу» [3]. Ми хотіли б звернути увагу на поняття "срера», яке дозволяє візуалізувати єдність спадковості й мінливості. Також уводиться поняття «антропний принцип», яке виражає потенційні можливості виникнення життя. Вони пов'язані зі значенням світових констант. Антропний принцип базується на припущенні про існування множини Всесвітів та виникненні життя там, де складаються для цього особливі умови. На певних етапах еволюції об'єктивні властивості Всесвіту як цілого створюють можливість виникнення життя, а у подальшому, - розуму.

Розвиток астрономії зумовив можливість емпіричної перевірки теорії Великого вибуху, теорії Всесвіту, що розширюється. Еволюційний процес живих речовин створив нову геологічну силу - наукову думку соціального людства, завдяки якій біосфера переходить у новий стан - ноосферу. Висувається припущення, що сила розуму дозволить вийти за межі планети. Жћиття розглядається як цілісний еволюційний процес (фізичний, геохімічний, біологічний), включений як особлива складова в космічну еволюцію [2, с. 423]. Вихід за межі планети має бути пов' язаний із виникненням еволюційної новації.

Завдяки теорії самоорганізації й термодинаміці нерівноважних станів виявлено механізми розвитку систем, які «кардинально перетворюють систему», забезпечують «перехід на більш високий рівень упорядкованості», «вибір шляху розвитку». Але поки що залишається невідомим новий спосіб збереження нових структур, що має еволюційне значення. Він пов' язаний із фактором «порядку». Теорії переконали в еволюції матерії, єдиній картині всесвітнього еволюційного процесу: неорганічний світ був розглянутий як складник еволюційного процесу поруч із біологічним $\mathrm{i}$ соціальним світом. Ідея цілісності доповнюється ідеєю єдності. Це має принципове значення для розуміння нового об’єкта пізнання.

Зазначені наукові здобутки дозволяють виділити важливі теоретичні положення про те, що: 1) для побудови єдиної картини еволюційного процесу соціальної матерії доцільно до уваги взяти значення світових констант; 2) еволюційний рух пов' язаний iз розширенням Всесвіту, тобто збільшенням просторових меж; це дозволяє пояснити тенденцію глобалізації соціального простору; 3) еволюційний рух матерії зумовлює безперервне ускладнення системи зі збереженням власної самототожності; це змушує орієнтуватись на генетично перші форми. Завдяки дії індивідуального фактору наука включила в дослідження нові процеси, які не були представлені у науковій картині світу. Парадокси у науці сигналізували про це. Їх осмислення й встановлення суперечностей завдяки суб'єктивному фактору зумовило зростання кількості явищ, які неможливо пояснити у межах діючої картини світу. Це є першою ознакою того, що картина світу й об’єкт пізнання мають бути переглянуті.

Педагоги й психологи вказують на суперечності в науці (Б. Ломов, В. Беспалько, О. Леонтьєв). По-перше, вони пов' язані з відсутністю відповідей на питання про те, як відбувається синтез знань, як забезпечити взаємодоповнюваність різних точок зору, як організовуються різноманітні властивості особистості в цілісну систему. Саме через це не вдається скласти цілісну модель особистості у психології й компетентності у педагогіці. Попри докладені зусилля, результати й ефекти професійної підготовки фахівців на різних рівнях освіти не диференційовані й недостатньо формалізовані. О. Леонтьєв констатує, що хоча психологія й намагалася розкрити склад особистості через інтеграцію даних про сенсорно-перцептивні, мнемічні, розумові, емоційні та інші психічні процеси, «скласти 3 них» цілісну особистість не вдалося. Індивідуально-своєрідна комбінація психічних процесів і станів особистості ще не дає достатньо повного уявлення про іï психологічний склад. Виникає питання про те, як організовуються різноманітні психологічні властивості особистості в цілісну систему [8, с. 292]. П. Анохін наголошує, що поза увагою дослідників залишається внутрішня архітектоніка системи, специфічні властивості її внутрішніх механізмів. Система може стати методологічним принципом дослідження та перекинути концептуальний міст від синтетичних узагальнень до аналітичних деталей у разі, 
якщо вона буде мати чітко окреслену, достовірну й логічно виправдану внутрішню архітектоніку, яка розкриває специфічні механізми $[9$, с. 45-46]. Оскільки йдеться не про один механізм, підтверджується припущення, що системний об'єкт має багатовимірний характер.

На нашу думку, неможливість вирішення виділених вище суперечностей пов'язана з ізольованим розглядом окремих підсистем (у тому числі особистості), а не складної системи як об'єкта, що еволюціонує.

Корисним для актуалізації неявного знання є метод герменевтичного аналізу, який дозволяє виділити у наукових текстах значущі положення. Хоча вони не набули провідне значення у концепції автора, але завдяки новій інтерпретації можуть виявитися корисними для побудови нових концептів.

Як зазначає Я. Пономарьов, функціонування взаємодіючої системи здійснюється шляхом переходів процесу у продукт і далі - продукту у наступний процес. Те, що на стороні процесу виступає в динаміці та може бути зареєстроване у часі, на стороні продукту виявляється у вигляді статичної властивості. Перехід на новий рівень пізнання дозволяе відкрити «чорний ящик», тобто пізнати структуру складного системно організованого об'єкта [4]. Заслуговують на увагу структурні особливості взаємодіючої системи: вона складається з кількох підсистем, є багатотовимірною. Підставою для такого умовиводу є положення про переходи «процесу у продукт, і далі - продукту у наступний процес». Фактично йдеться про еволюційний принцип, який дозволяє забезпечити взаємодоповнюваність різних точок зору.

Е. Маркарян наголошує, що виявити смисл взаємодоповнюваності різних точок зору можна лише у процесі вироблення відповіді на вузлові питання, пов'язані з обґрунтуванням загальної теорії культури, але саме ці питання поки не мають певного рішення $[10$, с. 36$]$. В. Слободчиков наголошуе на важливості обгрунтування побудови загальної теорії психічного розвитку як основи проєктування єдиної системи суспільного виховання підростаючих поколінь. Але для вирішення цієї масштабної задачі недостатньо будь-якої множини окремих теорій розвитку окремих властивостей та структур психічного (сприйняття, мислення, свідомості, особистості тощо) [11]. Відсутність таких теорій $\mathrm{e}$ наслідком існуючої картини світу, у якій суб'єкт і об'єкт розглядаються окремо. Через неврахування еволюційного руху матерії об'єктом пізнання завжди ставала підсистема, а не система як така, що володіє якостями життя й діяльності. Ознакою цього є поширення трьохвимірних моделей психіки, особистості, діяльності тощо.

Дослідниками скоріше відчувається, ніж усвідомлюється, необхідність перегляду об’єкта пі- знання. Вони визнають, що спрямування уваги на аналіз явищ, що спостерігаються під час експерименту, відволікає увагу від пізнання внутрішніх механізмів розвитку особистості. Пізнати структуру неможливо без пізнання механізмів розвитку. А. Братусь звертає увагу, що психологічна наука переважно досліджує особистість у цей момент, як незмінно тотожну самій собі, набір рис i якостей, що зафіксовані, при цьому залишаючи поза увагою внутрішні закони розвитку особистості, їі зміни у певному життєвому проміжку. Важливо фіксувати та визначати масштаби не розвитку людини як такої, який не має фіксованих меж, а встановлювати психологічні механізми, шляхи, які опосередковують цей розвиток, суттєво впливаючи на його хід і напрям [12].

Б. Ломов зауважує, що пошук передумов розвитку особистості спочатку відбувався з орієнтацією на з'ясування закономірностей розвитку ії компонентів. В одному випадку за основу бралися форми психічного відбиття, в другому - способи організації регулятивних або комунікативних функцій, у третьому - тип взаємодії людини із зовнішнім світом. Але слід враховувати, що розвиток кожної зі складових підпорядковується розвитку системи загалом [13, с. 96, 227]. Дослідником продемонстрована багатовимірність людини, а також специфічне значення розвитку. Але не було враховано, що особистість, - лише одна 3 іпостасей людини як деякої універсалії.

Завдяки соціальним комунікаціям наукові здобутки узагальнюються, набувають якісну визначеність - відбувається виникнення й зміна парадигм. Цей фактор ми розглядаємо як особистісній. 3 урахуванням необхідності врахування суб'єктивного виміру науки останні представляють інтерес для розуміння сутності ії̈ еволюційного руху.

3 позицій філософської науки В. Стьопіним у філософській концепції структури й генези наукової теорії в соціокультурному контексті обгрунтовується існування передумов зміни наукової парадигми. У науковій картині світу поступово стверджується уявлення про еволюцію соціальних об'єктів, що знаходять відображення у різних науках. Філософ як передумови зміни парадигми науки виділяє: визнання важливої ролі людини у процесах глобального еволюціонізму; зміну образу людини в психології, що виявляється у введенні власне людських виявів у сферу науки, у тенденції вивчення людини не тільки з точки зору іiї сторін, виявів та функцій, але і з позиції її унікальності, цілісності, єдності зі світом; визнання «суб'єктивного виміру» науки пов'язане з розповсюдженням методів гуманітарного пізнання, пошуком нових підходів і методів дослідження у психології й педагогіці; зміною смислу базових категорій педагогіки; підвищенням інтересу 
педагогів до осмислення основ теорій, філософських питань, а також накопиченням у педагогічній сфері проблем і суперечностей [3].

У парадигмальному знанні наявні стратегічно важливі ідеї й принципи. Якщо раніше увага зосереджувалась на процесах функціонування (кібернетичний підхід), далі - на процесах самоорганізації (синергетичний підхід), то на сучасному етапі і в перспективі поширюватиметься значення еволюційного руху матерії. Завдяки антропоцентричній парадигмі еволюційні процеси знову потрапили у поле зору науковців. Саме в новій парадигмі набуває визначеності ідея єдності об’єкта й суб’єкта, еволюції й розвитку, теорії й практики.

Сучасна антропоцентрична парадигма забезпечує збагачення ідеї цілісності ідеєю єдності. Єдність суб'єктивного й об'єктивного факторів представлена у тезі про те, що «детермінізм в описі світу не виключає випадковість - вони узгоджуються й взаємодоповнюють один одного: якщо в точці біфуркації діє (домінує) випадковість, непередбачуваність, то після вибору шляху розвитку, на етапі більш стійкого існування системи, в силу вступає детермінізм» [2, с. 30]. Наголошення на тому, що наука має розглядатись в єдності з позанауковими процесами, також $€$ ознакою нового бачення світу, у якому забезпечується включення суб'єкта в об'єкт пізнання. «Концепція самоорганізації розширює межі дисципліни, для її характеристики особливе значення мають міждисциплінарні відношення, а також процеси, що відбуваються поза наукою» [2, с. 22]. На основі вищезазначеного можна констатувати виникнення нового об'єкта наукового пізнання - глобальних еволюційно-ієрархічних систем. У цьому разі система, що самоорганізовуються, має бути розглянута не як самостійна система, а як підсистема більш складної універсалії - системи, яка еволюціонує.

У методологічному відношенні слушні ідеї щодо виділення еволюційно-ієрархічних рівнів Світу, отже, і відповідних систем, як висловлює О. Болдачов. Традиційно для виділення ієрархічних рівнів застосовувалось два способи - хронологічний (часовий) або просторово-структурний аналіз. Вони відбивають дві обов'язкові (постульовані) сторони еволюційного процесу: його розгортання у часі та ускладнення просторової структури систем, які еволюціонують. У першому разі слід виходити з однозначно виділених етапів еволюції, які складають ієрархічні рівні, за принципом «що за чим слідувало» (біологічний етап передував соціумному). У другому разі, аналізуючи структуру об’єктів, можна виділити ієрархію за принципом «що з чого складається» (елементом суспільства є біологічний організм, представник виду Homo Sapiens). Але не завжди те, що з'явилося пізніше, складає новий ієрархічний рівень (астрономічні об'єкти сформувались пізніше атомарного етапу, але не можуть розглядатись як са- мостійний рівень). Так само не завжди елементам складної просторової системи можна поставити у відповідність еволюційно-ієрархічний рівень (організм складається з органів, але вони не складають окремий еволюційний рівень). Тільки сполучивши обидва підходи (принцип єдності хронологічної та просторової ієрархій), можна підійти до виділення еволюційно-ієрархічних рівнів Світу. Він має вписуватись у хронологічний ланцюг, тобто його формування має слідувати за часом за появою нижчого рівня ієрархії та передувати вищому (органи сформувались одночасно з організмом); основними елементами вищого рівня ієрархії мають бути деякі системи (організми) нижчого рівня - просторовий принцип (астрономічні об’ $€ \kappa$ ти не є рівнем, їх системи не є елементами ніякого іншого вищого відносно їх рівня ієрархії) [14].

Поєднання хронологічного й структурно-просторового підходів дає можливість виділити ще одне представлення еволюційно-ієрархічних рівнів: як реальних, що існують у часі і просторі самостійних систем, - таких, що еволюціонують. На кожному еволюційному етапі об'єкти, що специфічно взаємодіють, можна представити як єдину еволюційно-ієрархічну систему. Пропонується додавати до їх назви епітет «глобальні», щоб підкреслити відмінність від локальних об’єктів, що просторово виділені.

Глобальні еволюційно-ієрархічні системи є реальними об'єктами Світу. Початок їх формування збігається з початком однойменного еволюційного періоду, а організація відповідає ієрархічному рівню. Наприклад, біосфера як цілісна система сформувалася на біологічному етапі еволюції та як елементи включає в себе об'єкти - планети, поєднані біологічними взаємодіями. Еволюційні системи зберігають свою визначеність і цілісність після завершення відповідного етапу еволюції. Вони $€$ основою для формування наступних еволюційноієрархічних систем. Біосферу можна розглядати як основу для становлення ноосфери. На відміну від одновимірних уявлень, глобальні еволюційноієрархічні системи є багатовимірними.

У цій ситуації актуалізується проблема термінологічного позначення такої системи. Становлення загальнонаукової картини світу стимулює до пошуку й обгрунтування єдиної термінологічної системи для опису ізоморфних (гомоморфних) систем, зокрема соціальних. Зближення наук передбачає орієнтацією на пошук універсальних загальнонаукових понять, придатних для опису та пояснення процесів у різних предметних галузях. Наприклад, такими є поняття «система», «структура», «функція», «самоорганізація», «розвиток», «еволюція», «антропний принцип». Йдеться про перехід на загальнонауковий рівень вирішення прикладних завдань педагогіки, методики, дидактики (а також інших наук). Зазначені тенденції мають бути 
враховані під час вибору варіанту термінологічного позначення нового об’єкта дослідження.

Складна система традиційно розглядається за характеристиками більш високого рівня організації. Так, системи, елементом яких є людина, позначаються як соціальні. Але таке бачення $є$ спрощеним, адже поняття «людина» є складним (інваріантним). Мова може йти про індивіда, індивідуальність, особистість. До того ж під час розгляду соціальних систем не брався до уваги ïх біологічний фундамент. 3 урахуванням нових ціннісно-світоглядних орієнтирів, які знайшли відображення в антропоцентричній парадигмі, а також тенденції інтеграції наук, існують підстави для позначення нового об'єкта дослідження концептом Людина, який має універсальне значення. Відповідно, діюча модель такого об'єкта, - інваріантна модель антропоцентричної системи. На відміну від соціальної системи, яка є об’єктом дослідження у некласичній науці, антропоцентрична система представляє не тільки соціальну якість в єдності зі своїм біологічним фундаментом, а й фіксує результати її еволюційного руху.

Перетворення не є таким переходом одної якості в іншу, за якої перша зникнула б, була витіснена та замінена другою. Висхідний стан зберігається у перетвореному вигляді у новій, більш складній системі, фундаментом якої воно було і у складі якої воно утрималося. Біологічна життєдіяльність залишається матеріальною базою, на якій вибудовується споруда соціокультурної реальності, але ця остання вбирає у себе свій біологічний фундамент, не дозволяючи йому функціонувати у чистому вигляді [1]. «Історична еволюція характеризується переходом від одної, відносно стійкої системи, до іншої системи 3 новою рівневою організацією елементів та саморегуляцією» [3]. Властивості людини (відбиття й активність, інтелект й емпатія) створюють підгрунтя виникнення нових еволюційних форм, але самі не зникають, а зберігаються в антропоцентричній системі у нових формах.

Ідея антропоцентризму сформульована Сократом ще в античній філософії, де людина і Всесвіт перебувають у розумній та доцільній гармонії, зумовленій божим задумом. Розумність світобудови відповідає матеріальним і духовним потребам людини. Реалізувати свою місію людина може тільки у процесі самопізнання й життя задля істини. За Аристотелем, діяльність людини має актуальну мету, а явища природи - потенційну, що реалізується у процесі розвитку самого предмета. Людина стає учасником іманентного розвитку світу в прагненні до Бога як до кінцевої мети, до самої себе [15].

Поняття «антропоцентризм» уведене в епоху Відродження. Воно позначає принцип, відповідно до якого людина є завершенням еволюції світобудови. Поняття «центру» й «периферії» $є$ важливим у відображенні тенденцій еволюційних змін.
Під антропоцентричною системою будемо розуміти клас еволюційно-ієрархічних систем, вершиною яких є людина як динамічний момент завершення еволюції світобудови.

Висновки.

1) Накопичення парадоксів привело до перегляду наукової картини світу й виділення нового об’єкта науки. На сучасному етапі відбувається становлення загальнонаукової картини світу, що базується на принципі глобального еволюціонізму. Одним із чинників цього процесу стало виникнення нового предмету дослідження - систем, що самоорганізовуються. Проблеми, поставлені науковцями у філософській, психологічній, педагогічній, а також інших науках, зумовлюють необхідність оновлення наукової картини світу, отже, переосмислення об’єкта дослідження.

2) Критичний аналіз індивідуального, суб’єктивного, особистісного факторів дозволяє констатувати становлення нового типу об'єкта наукового пізнання - людини як антропоцентричної системи. Системи, що самоорганізовуються, так само, як i системи, що саморегулюються, слід розглядати як предмет, а не об'єкт науки. Справжнім об’єктом є ієрархічно-еволюційні системи, які можуть бути позначені як антропоцентричні системи.

3) Антропоцентрична система представляє соціальну якість у єдності зі своїм біологічним фундаментом. Для виділення класу зазначених систем важливо орієнтуватись на принцип єдності хронологічної та просторової ієрархій (О. Болдачов).

4) Інваріантна модель антропоцентричної системи як універсальної організації соціальної системи, що виникає на основі біологічного фундаменту, може виступати як методологічний засіб для розробки варіативних структур.

\section{Jimepamypa}

1. Уваров Е.А. Саморазвивающиеся системы: теоретико-методологический анализ. Гаудеалус. 2003. № 2 (4).

2. Василькова В.В. Порядок и хаос в развитии социальных систем. Санкт-Петербург : Лань. 1999. 480 с.

3. Степин В.С. Теоретическое знание. Москва : Прогресс-Традиция, 2000. 744 с

4. Эбелинг В. Образование структур при необратимых процессах. Введение в теорию диссипативных структур. Москва-Ижевск : институт компьютерных исследований, 2003.

5. ПономаревЯ.А. Психология творчества. Москва: Наука. 322 с.

6. Maruyama M. The Second Cybernetics: Deviation-Amplifying Mutual Causal Processes. American Scientist. 1963. P. 164-179.

7. Человек: Философские аспекты сознания и деятельности / Т.А. Адуло, А.И. Антипенко, Е.А. Алексеева и др.; Под ред. Д.И. Широканова, А.И. Петрущика. Минск : Наука и техника, 1989. С. 32-63.

8. Леонтьев А.Н. Деятельность. Сознание. Личность. Москва : Политиздат, 1975. 344 с.

9. Анохин П.К. Избранные труды: Кибернетика функциональных систем /Под ред. К.В. Судакова. сост. В.А. Макаров. Москва : Медицина, 1998. 400 с. 
10. Маркарян Э.С. Теория культуры и современная наука (логико-методологический анализ). Москва : Мысль, 1983. 145 с.

11. Слободчиков В.И., Исаев Е.И. Психология развития человека. Развитие субъективной реальности в онтогенезе: учебное пособие. Москва : Издательство ПСТГУ, 2013. 400 c.

12.Братусь Б.С.Аномалии личности. Москва : Мысль, 1988, 348 с.

13. Ломов Б.Ф. Методологические и теоретические проблемы психологии. Москва : Наука. 1984. 444 с.

14.Болдачев А.В. Новации. Суждения в русле эволюционной парадигмы. Санкт-Петербург : Издательство Санкт-Петербуржского университета, 2007. 256 с.

15. Соколов В.Ю. Антропоцентризм / Енциклопедія Сучасної України: електронна версія / гол. редкол. I.M. Дзюба, А.І. Жуковський, М.Г. Железняк та ін. Київ : інститут енциклопедичних досліджень НАН України, 2006 URL: https://esu.com.ua.search_articles $\mathrm{id}=43068$

\section{Анотація}

Копилова C. В. Антропоцентрична система як об'єкт сучасного пізнання. - Стаття.

У статті поставлена проблема осмислення глобальних еволюційно-ієрархічних систем як нового об’єкта пізнання. На основі критичного аналізу факторів виділено суперечності у науці, які зумовлюють необхідність перегляду наукової картини світу, а також зміну парадигми некласичної науки. Неможливість вирішення суперечностей у науці пов'язана з ізольованим розглядом окремих підсистем (у тому числі особистості, компетентності), а не складної системи як об'єкта, що еволюціонує. Здобутки конкретних наук, у тому числі соціально-гуманітарних, дозволяють осмислити тенденції розвитку різних видів знання. Завдяки еволюційному принципу створено передумови синтезу наукового знання, що актуалізує значення багатовимірного мислення в осягненні дійсності. У XXI столітті відновився інтерес дослідників до систем, що еволюціонують, але тепер уже на якісно іншому рівні. На кожному еволюційному етапі об’єкти, що специфічно взаємодіють, можна представити як єдину еволюційно-ієрархічну систему.

Проаналізовано можливості термінологічного позначення нового об'єкта дослідження постнекласичної науки. При цьому враховано, що становлення загальнонаукової картини світу стимулює до пошуку й обгрунтування єдиної термінологічної системи для опису ізоморфних систем. Йдеться про перехід на загальнонауковий рівень вирішення прикладних завдань педагогіки, методики, дидактики (а також інших наук).

3 урахуванням нових ціннісно-світоглядних орієнтирів, які знайшли відображення в антропоцентричній парадигмі, а також тенденції інтеграції наук, існують підстави для позначення нового об’єкта дослідження, - «антропоцентрична система». Основними концептами, що мають універсальне значення в постнекласичній науці, є: Людина, еволюція, патерн. Властивості людини (відбиття й активність, інтелект й емпатія) створюють підгрунтя виникнення нових еволюційних форм матеpii, але самі не зникають, а зберігаються в структурі антропоцентричної системи. Під антропоцентричною системою будемо розуміти клас еволюційно-ієрархічних систем, вершиною яких є людина як динамічний момент завершення еволюції світобудови.

Ключові слова: антропоцентрична система, антропоцентрична парадигма, еволюція, багатовимірність, Людина

\section{Summary}

Kopylova S. V. Anthropocentric system as an object of modern cognition. - Article.

The article poses the problem of understanding global evolutionary-hierarchical systems as a new object of cognition. On the basis of a critical analysis of the factors, contradictions in science are identified, which necessitate a revision of the scientific picture of the world, as well as a change in the paradigm of non-classical science. The impossibility of resolving contradictions in science is associated with an isolated consideration of individual subsystems (including personality, competence), and not a complex system as an evolving object. Achievements of specific sciences, including social and humanitarian ones, make it possible to comprehend the tendencies in the development of knowledge. Thanks to the evolutionary principle, the prerequisites for the synthesis of scientific knowledge have been created, which actualizes the significance of multidimensional thinking in comprehending reality. In the 21 st century, the interest of researchers in evolving systems has revived, but now at a qualitatively different level. At each evolutionary stage, specifically interacting objects can be represented as a single evolutionary-hierarchical system.

The possibilities of terminological designation of a new object of research in post-nonclassical science are analyzed. At the same time, it is taken into account that the formation of a general scientific picture of the world stimulates the search and substantiation of a single terminological system for describing isomorphic systems. We are talking about the transition to the general scientific level of solving applied problems of pedagogy, methodology, didactics (as well as other sciences).

Taking into account the new value and worldview guidelines, which are reflected in the anthropocentric paradigm, as well as the trends in the integration of sciences, there are grounds for designating a new object of research - the "anthropocentric system". The main concepts that have universal significance in post-nonclassical science are: Man, evolution, pattern. Human properties (reflection and activity, intelligence and empathy) create the basis for the emergence of new evolutionary forms of matter, but they themselves do not disappear, but remain in the structure of the anthropocentric system. Under the anthropocentric system we mean a class of evolutionary-hierarchical systems, the top of which is a person as a dynamic moment of completion of the evolution of the universe.

Key words: anthropocentric system, anthropocentric paradigm, evolution, multidimensionality, human. 